Vol 3, No 2 (2020): Stadium-Hungarian Journal of Sport Sciences

https://doi.org/10.36439/SHJS/2020/2/8600

\title{
AZ ÁRAMLATÉLMÉNYRE VALÓ HAJLAMOSSÁG, A TELJESÍTMÉNYMOTIVÁCIÓ ÉS A KONTROLLHELY KAPCSOLATA KETTŐS KARRIERÛ́ SPORTOLÓK KÖRÉBEN
}

\author{
THE RELATIONSHIP BETWEEN FLOW PRONENESS, ACHIEVEMENT MOTIVATION AND LOCUS \\ OF CONTROL AMONG DUAL CAREER ATHLETES
}

Tóth Máté, Kiss Brigitta

Debreceni Egyetem, BTK, Pszichológia Intézet, Debrecen

\begin{abstract}
Összefoglaló
A csúcsteljesítmény elérése a profi sport egyik legföbb céljának tekinthetö, és szorosan összefügg a sportolói áramlatélményekkel. Ebből kifolyólag a sportolói flow-élmények háttértényezőinek vizsgálata kiemelten fontos. Jelen kutatás során az áramlatélményre való hajlamosság, a teljesítménymotiváció és a kontrollhely feltételezett kapcsolatát vizsgáltuk egy kettős karrierü sportolói mintán. Emellett a sportflow univerzalitását is teszteltük. A mérésekhez Oláh (2005) Flowkérdő́ivét, Lang és Fries (2006) Teljesítménymotiváció Kérdőivét és Rotter (1966) Külsô-Belső Kontroll Attitüd Skáláját alkalmaztuk, a tesztcsomag online, hólabda-módszer segítségével terjesztettük. A mintát 178 kettős karrierü sportoló képezte. Az eredmények alapján megállapítható, hogy a teljesítménymotiváció és a belsô kontrollhely is szignifikáns kapcsolatban áll az áramlatélményre való hajlamossággal, illetve a flow univerzális jelenségnek bizonyult.
\end{abstract}

Kulcsszavak: flow, teljesítménymotiváció, kontrollhely, kettős karrier

\begin{abstract}
Achieving peak performance is strongly connected to athletic flow experiences, and it is also considered one of the main goals in professional sports. For this reason, it essential to systematically examine any contributing factor connected to athletes' flow proneness. This study examined the assumed connection between flow proneness, achievement motivation, and locus of control among dual-career athletes. Furthermore, the universality of sport flow experiences was also tested. We used Oláh's (2005) Flow Questionnaire, Rotter's (1966) Internal-External Locus of Control Scale, and the Achievement Motivation Test developed by Lang and Fries (2006). The test was shared online by the snowball method, and the sample consisted of 178 dual career athletes. According to the results, there is a significant connection between flow proneness, achievement motivation, and locus of control. The universality of flow was also proven.
\end{abstract}

Keywords: flow, achievement motivation, locus of control, dual career 


\section{ELMÉLETI HÁTTÉR}

Az élsport világában a legfőbb cél a csúcsteljesítmény elérése, tehát kulcsfontossággal bír minden hozzájáruló faktor detektálása és vizsgálata. Ezen a területen kiemelendő az áramlatélmény, mely folyamatosan motivál a maximális teljesítmény produkálására (CSÍKSZENTMIHÁLYI - JACKSON, 2001).

A csúcsteljesítmény pillanatában az élsportolók Ravizza vizsgálatai alapján a következőket érezték: szűk fókuszú figyelem a tevékenységre irányulva, teljes mértékű bevonódás, teljes kontroll érzete bármilyen erőlködés nélkül és az időélmény megváltozása (RAVIZZA, 1977). Ezen szubjektív tapasztalatok eredménye nagyon hasonló a flow élményéhez, tehát összefüggés feltételezhető a két állapot között, mely kapcsolatot több empirikus kutatás eredménye alátámaszt (JACKSON et al., 2001; STAVROU et al., 2007).

A flow kutatási területének úttörője, Csíkszentmihályi Mihály szerint a tökéletes élmény során olyan mértékben összeolvadunk az aktuálisan végzett tevékenységgel, hogy az teljesen kizárja bármilyen zavaró gondolat vagy érzés tudatba törését (CSÍKSZENTMIHÁLYI, 2010). Az élmény tökéletessége nem az akadályok hiányából fakad, hanem abból az érzésből, hogy saját sorsunk kovácsaként teljes mértékben mi kontrolláljuk az életünket. Így, a testi és a lelki szféra optimális kooperációja és a koncentráció erőteljes fókusza mellett képes az ember számára egy egészen egyedülálló élményt nyújtani. Mindennél hangsúlyosabb a tapasztalat szubjektivitása, a belső világ aktív kontrollálása. Az aktivitás különösen fontos, ugyanis legmeghatározóbb élményeink és sikereink túlnyomórészt saját akaratunk érvényesítése által valósultak meg egy számunkra fontos cél érdekében (CSÍKSZENTMIHÁLYI, 2010).

A flow univerzális, tehát megtapasztalása független többek között a kortól, a nemzetiségtől, valamint a végzett tevékenység minőségétől (CSÍKSZENTMIHÁLYI JACKSON, 2001). Ebből következik, hogy a tökéletes élmény megtapasztalásának valószínűsége független a sporttevékenyég típusától vagy a sportoló demográfiai jellemzőitől. Csíkszentmihályi és Jackson (2001) nyolc pontban összegezték a sportflow egyetemes feltételeit, melyek a következők:

1. Kihívás-készség egyensúly

2. A cselekvés és a tudat összeolvadása

3. Világos célok

4. Egyértelmű visszajelzések

5. Kontroll érzése

6. Feladatra való koncentrálás

7. Önmagunkkal kapcsolatos tudatosság elhalványulása

8. Időélmény átalakulása

A kihívás-készség egyensúly a sportoló előtt álló feladat szubjektív nehézségének és az észlelt képességek arányosságából fakad. Ha a kihívás túlságosan meghaladja képességeinket, akkor szorongás és aggodalmak jelennek meg, míg túl könnyű feladat 
során az unalom zárja ki a flow lehetőségét. Mindkét komponens alacsony szintje esetén gyakorlatilag megvalósul az egyensúly, ekkor azonban az arousal alacsony szintjéből következve egy közönyös, apatikus állapotról beszélhetünk. Ezen gondolatmenet alapján az áramlatélményhez nagy kihívások és kiváló képességek szükségesek, természetesen a szubjektív észleletek szintjén (OLÁH, 1999).

A cselekvés és a tudat összeolvadása alatt azt értjük, hogy a sportoló a teljesen elmerül a végzett tevékenységben pszichikus energiái aktív használata révén, tehát zavaró tényezőknek nincs helye a tudatban. Fontos, hogy a sportoló világos célokat állítson, mivel konkrét irányt biztosítanak a figyelem számára. Ez a céltudatosság vagy egyszerúbben csak tudatosság mérhetetlen önbizalmat kölcsönöz az embernek. Az említett magabiztossághoz elengedhetetlenek az egyértelmú visszajelzések, hiszen a visszacsatolás kulcsfontosságú információval szolgál a saját teljesítményről (CSíKSZENTMIHÁLYI JACKSON, 2001).

$\mathrm{Az}$ önbizalomhoz szorosan kapcsolódik a kontroll érzése, ugyanis a flow megtapasztalásának pillanataiban a sportoló úgy érzi, teljesen ura a helyzetnek, és sorsa a saját kezében van. Ez az érzés az észlelt kihívás-készség egyensúlyból fakad, ugyanis ebben a helyzetben úgy érezzük, hogy észlelt készségeink megfelelő szintűek az előttünk álló feladat sikeres elvégzéséhez (CSÍKSZENTMIHÁLYI - JACKSON, 2001).

A következő összetevő a feladatra való koncentrálás. Az áramlatélmény közben a figyelem csakis kizárólag az aktuálisan végzett tevékenységre irányul kizárva minden zavaró külső ingert és gondolatot. Emellett a külső zavaró tényezők automatikus ignorálása mellett az önmagunkkal kapcsolatos tudatosság elhalványulása is kiemelendő. A tudatosság negatív gondolatokat, aggodalmakat és szorongást tartalmaz. Ha ezeket elengedjük, a felszabadult sportoló már képes teljesen tudatosan a feladatra koncentrálni, és a feladattal való összeolvadás következtében pillanatnyilag nem marad kapacitás az ént érintő gondolatok létrejöttére (CSÍKSZENTMIHÁLYI - JACKSON, 2001).

Az utolsó dimenzió az idóélmény átalakulása. Az áramlatélmény közben perceknek érezhetünk órákat, vagy akár hosszabbnak is észlelhetünk másodperceket. Csíkszentmihályi és Jackson (2001) szerint ez az összetevő nem univerzális, de igen gyakori velejárója a flow állapotának. Értelemszerűen e torzult időérzékelés egy aspektusa kizárható, hiszen nem érintheti a feladatreleváns idői tényezőket, például a mozdulatok időzítését. Sőt, az áramlathoz szorosan kapcsolódó sportolói csúcsteljesítmény során e készség flow állapotban müködhet a leghatékonyabban. A felsorolt fundamentális komponensek a különböző szintű sporttevékenységeket tekintve egyaránt érvényesek.

Végül a flow-elmélet szerves részét képezi az áramlatélményre hajlamos, autotelikus személyiség. Több száz interjú anyaga alapján a flow élményeket gyakrabban megtapasztalók magabiztosabbak, nyitottabbak és nagyobb önkontrollal rendelkeznek. Továbbá hajlamosabbak saját, belső örömszerzés céljából és nem külső célok által motivált tevékenységek végzésére (CSÍKSZENTMIHÁLYI, 2010). 
Vol 3, No 2 (2020): Stadium-Hungarian Journal of Sport Sciences

https://doi.org/10.36439/SHJS/2020/2/8600

\section{SPORTFLOW, MOTIVÁCIÓ ÉS KONTROLL}

Ami a sportolói áramlatélményeket illeti, Jackson (1992; 1995) kvalitatív munkáiban említi, hogy az önbizalom és a teljesítménymotiváció is meghatározó faktornak tekintendő. További fontos befolyásoló tényező a versenyzés előtti optimális arousalszint elérése. Az arousal-szint párhuzamba állítható a kihívás-készség egyensúly dimenziójával, ugyanis mindkettő hasonló elvekre épül. Ha túl kicsi a kihívás, akkor az arousal szintje alacsony marad, és Csíkszentmihályi szerint az unalom és apátia állapotába kerül a sportoló. Ezzel szemben a készségeket túlságosan meghaladó feladatok végzése során az arousal az optimális szintet túllépi, és szorongás vagy düh jelentkezhet, mely állapotok ugyancsak gátolják a tökéletes élmény létrejöttét (CSÍKSZENTMIHÁLYI, 2010).

Csíkszentmihályi koncepciójában kiemelt szerepet kap a kihívás-készség egyensúly, tehát az előttünk álló feladat egyfelől nem lehetetlen, másfelől elvégzése megfelelő mennyiségű erőfeszítést igényel (CSÍKSZENTMIHÁLYI, 2010). A nehézségalapú feladatválasztási preferenciák egyértelműen különböznek a teljesítménymotiváció különböző szintjei esetében. Egyfelől az alacsony teljesítménymotivációjú személyek azokat a feladatokat részesítik előnyben, melyek a nehézség spektrumának két végpontján találhatók. Ezt a kudarc kerülésének igénye okozza, hiszen egy könnyű feladatot nagy valószínűséggel lehet sikeresen teljesíteni, míg egy nagyon komplikált kihívás esetében a siker valószínűtlen, így a kudarc megítélése is ennek tükrében változik (CARVER - SCHEIER, 2006). Velük szemben a magas teljesítménymotivációjú személyek a közepesen nehéz feladatokat kedvelik. A közepes szintű megmérettetés olyan kihívást jelent, mely erőfeszítést és viszonylagosan magas szintű képességeket igényel, de nem lehetetlen a teljesítése (CARVER - SCHEIER, 2006).
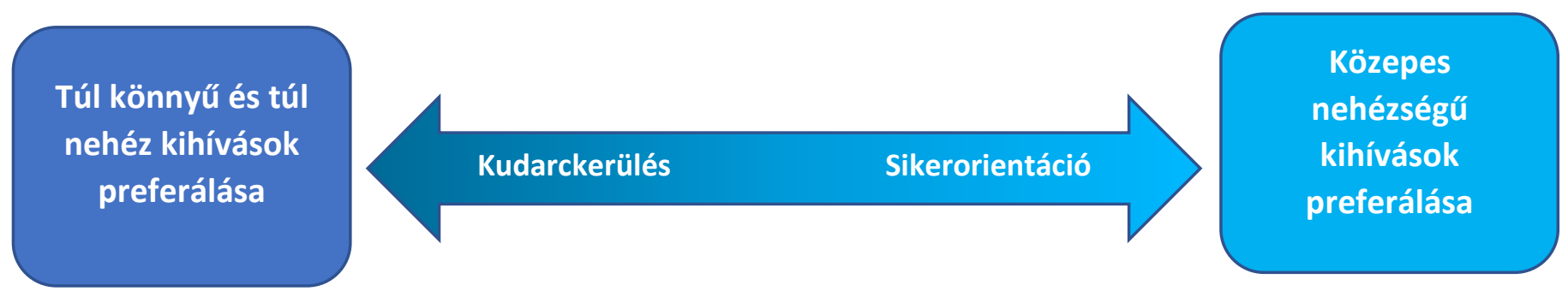

1. ábra: a sikerorientált és a kudarckerülő személyek feladatválasztási preferenciái (saját forrás)

Csíkszentmihályi érvelése alapján a két csoport közül az utóbbi eleve nagyobb eséllyel tapasztalhat flow-élményeket. Emellett az áramlatélményt gyakrabban megtapasztalók és a sikerorientált személyek több változó esetében hasonlítanak például az önbizalom vagy a kitartás területén, míg a kudarckerülők szorongása és képességeikbe vetett hitük hiánya akadályozza az áramlatélmény megtapasztalását (FODOR, 2007). 
A flow-elmélet másik, ugyancsak fontos komponense a kontroll érzete, hiszen az áramlat során saját kezünkben érezzük a sorsunkat. A cselekedeteink befolyásolják a körülöttünk lévő világot, folyamatosan változásokat generálnak, mely változásokat megerősítőkként értelmezünk. Mindazonáltal ezen megerősítők értelmezése egyénenként különbözhet, hiszen egyesek a szerencsét, a sorsot, vagy külső erők hatalmát hangsúlyozzák, míg mások a saját magatartásuk következményeként magyarázzák a velük történő eseményeket (ROTTER, 1966). Ebben az értelemben beszélhetünk külső kontrollos személyekről, akik esetében a külső megerősítők szerepe a jelentősebb, illetve belső kontrollos egyénekről, akiknek a legtöbb cselekedetét belsőleg vezéreltség jellemzi (KÖRMENDI - SZTANCSIK, 2013). Minél inkább a belső irányba mozdul a kontrollhely, annál hangsúlyosabbá válik a proaktivitás, a hatékony teljesítmény vagy a kitartás. Ezek a személyek úgy érzik, az események kimenetele irányításuk alatt áll, és képesek úgy befolyásolni közvetlen környezetüket, hogy megvalósítsák saját céljaikat (PETTERSEN, 1987). Ezzel ellentétben az inkább külső kontroll jellemezte emberek úgy érzik, viselkedésüket externális faktorok befolyásolják, kevésbé hisznek saját erőfeszítéseikben, változtatási képességükben (KÖRMENDI - SZTANCSIK, 2013). Úgy vélik, sorsuk nem a saját kezükben van, életüket pedig a szerencse vagy más véletlenek határozzák meg (PETTERSEN, 1987).

A viselkedés megerősítőit tekintve az autotelikus személyiség a belső örömöket preferálja, a környezeti eseményeket pedig egyénileg befolyásolhatónak tekinti, ami megegyezik a Rotter-féle kontrollhely-elmélet belső kontrollos személy jellegzetes gondolkodásmódjával.

A szakirodalom részletes áttekintését követően feltételeztük, hogy minél sikerorientáltabb és minél kevésbé kudarckerülő a sportoló, annál hajlamosabb az áramlatélmény átélésére. Továbbá feltételeztük, hogy a belső kontrollos sportolók ugyancsak nagyobb eséllyel élnek át flow-élményeket. Végül a csapatsportolók és az egyéni sportolók, illetve a nemek összehasonlításával az áramlatélmény univerzalitását teszteltük.

\section{MÓDSZER}

Kutatási módszerként kérdőíves eljárást alkalmaztunk. Az áramlatélményre való hajlamosságot Oláh (2005) Flow kérdőívével mértük, mely egy rugalmasan alakítható szituáció-reakció eljárásnak minősül. A teljesítménymotiváció vizsgálata Lang és Fries (2006) Teljesítménymotiváció kérdőívével történt, melyben öt-öt item vonatkozik a sikerorientáció és a kudarckerülés alskáláira, a teszt magyar verziója pedig Fodor és Mihalik (2017) nevéhez fűződik. Végül a kontrollhely mérése Rotter (1966) Külső-Belső Kontroll Attitűd Skáláját használtuk. A skálában megadott állításpárokból történő választás alapján következtethetünk a vizsgált személyek külső-belső kontroll kontinuumon való elhelyezkedésére.

A fentebb részletezett teszteket egy demográfiai kérdőívvel kiegészítve online módon lehetett elérni, a tesztcsomag hólabda-módszer alkalmazásával érte el a célcsoportot, mely a profi sport egy szúkebb szegmense, kettős karrierű sportolók voltak. 
Vol 3, No 2 (2020): Stadium-Hungarian Journal of Sport Sciences https://doi.org/10.36439/SHJS/2020/2/8600

A vizsgálati minta 178, igazolt és egyetemi hallgatói jogviszonnyal rendelkező sportolóból, 80 férfiból és 98 nőből állt. A minta arányos eloszlással jellemezhető versenyzési szintek szempontjából is, mind a sportágakat, mind a versenyzési szinteket tekintve, ezt a lentebbi ábrák is demonstrálják.

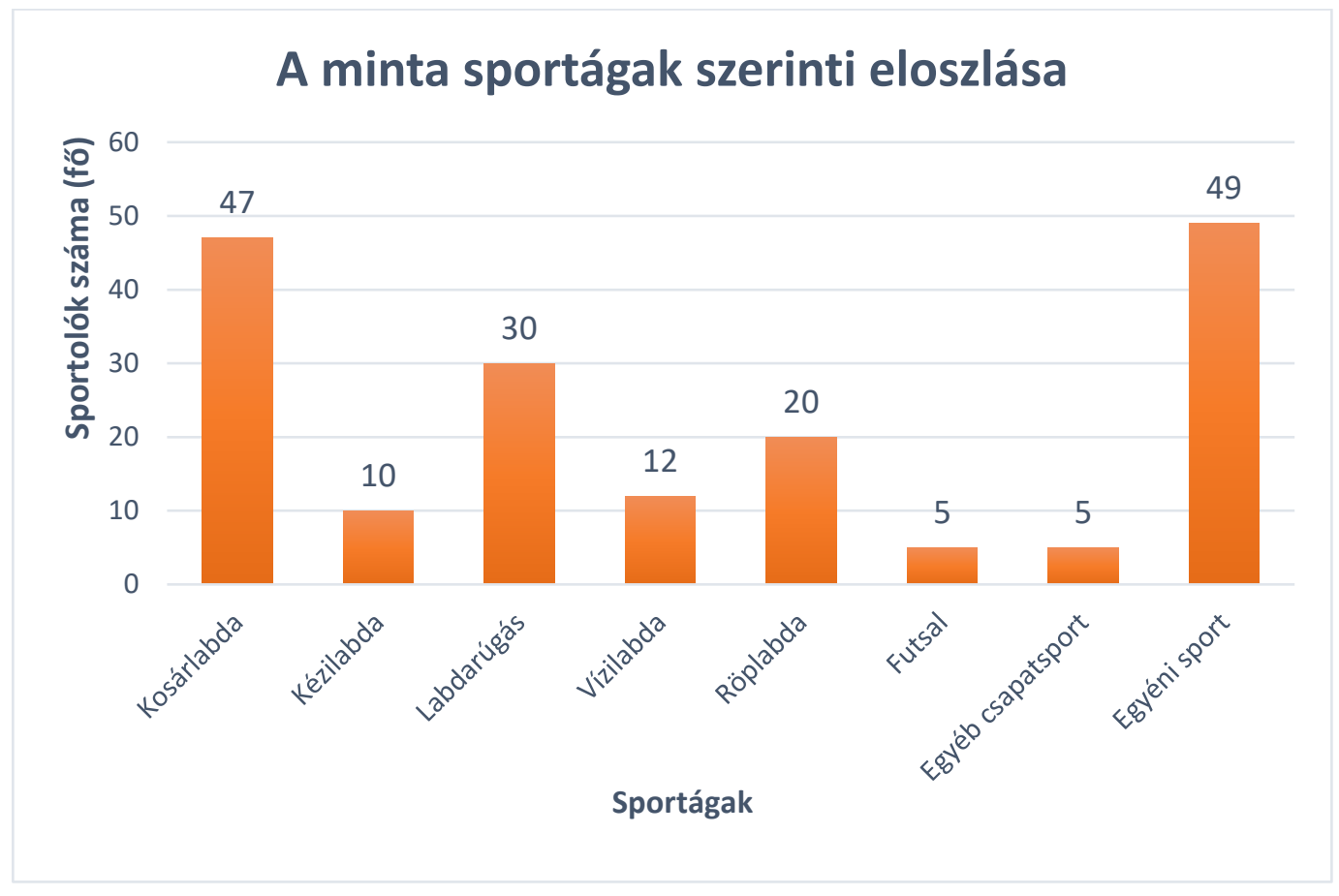

2. ábra: A minta sportágak szerinti eloszlása (saját forrás)

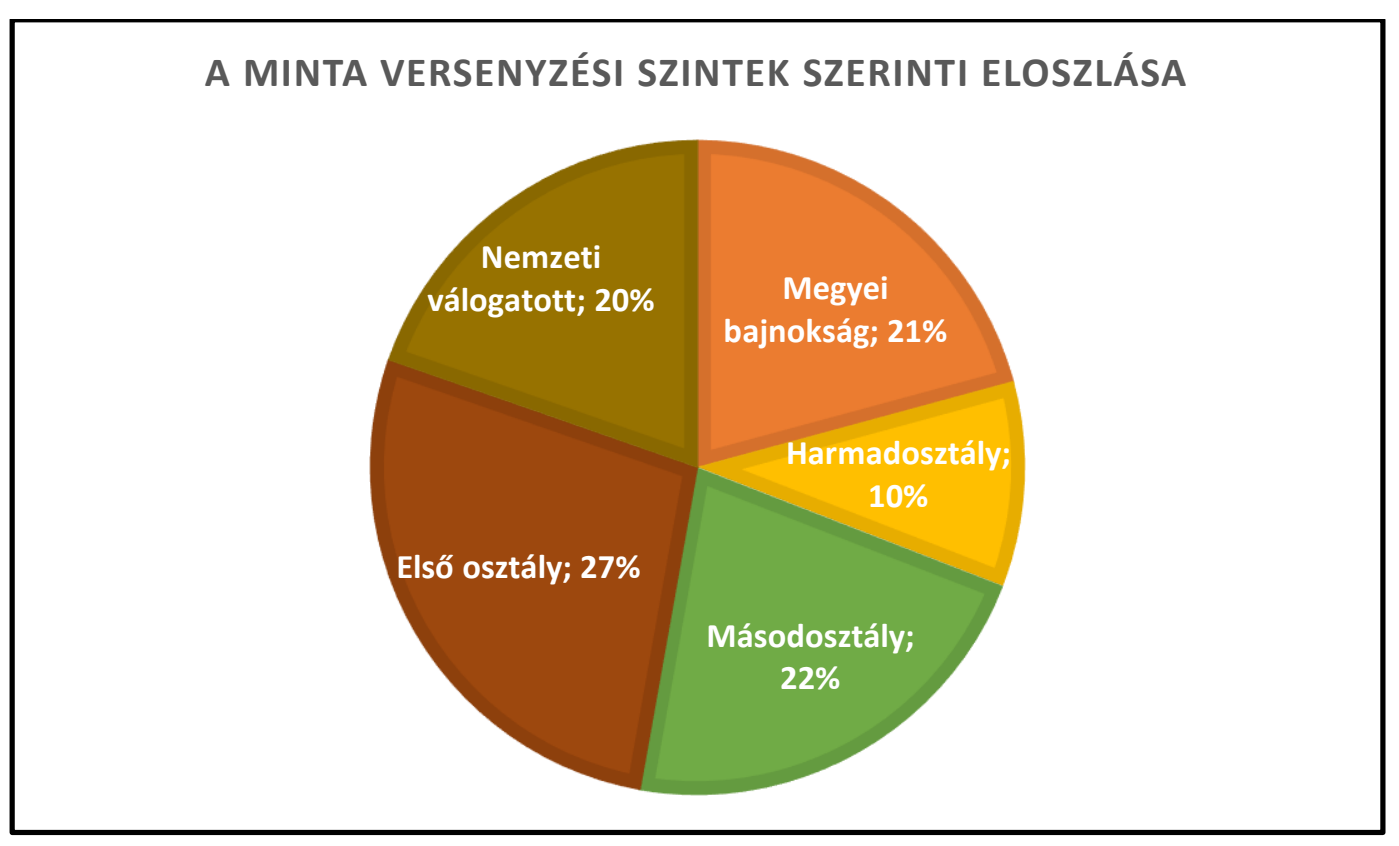

3. ábra: a minta versenyzési szintek szerinti eloszlása (saját forrás) 


\section{EREDMÉNYEK}

Az adatelemzés az SPSS statisztikai szoftver v.20.0 verziójának használatával zajlott. Az áramlatélményre való hajlamosság és a teljesítménymotiváció közötti feltételezett kapcsolat vizsgálata során a Spearman-féle rangkorrelációs tesztet alkalmaztuk. Szignifikáns összefüggést találtunk a teljesítménymotiváció mindkét alskálája esetében, tehát a sikerorientáció $(r=0.424 ; \mathrm{p}<0,001)$ és a kudarckerülés $(r=-0,203 ; p=0,007)$ is biztos kapcsolatban áll a sportolói flow-hajlamosság mértékével.

A kontrollhely esetében ugyancsak Spearman-féle rangkorrelációs tesztet használtunk, melynek eredménye alátámasztotta előzetes elképzeléseinket, mivel negatív szignifikáns kapcsolatot találtunk a kontrollhely pontszámok és az áramlatélményre való hajlamosság értékeivel $(r=-209 ; p=0,05)$. A korreláció negativitása alátámasztja a belső kontroll és a flow kapcsolatát, mivel Rotter tesztje a külső kontroll mértékét méri egy kontinuumon, vagyis az alacsonyabb pontszámok a Külső-Belső Kontroll Attitűd Skálán inkább a belső kontroll túlsúlyára utalnak.

Ami a flow univerzalitását illeti, Mann-Whitney teszt segítségével összehasonlítottuk a csapatsportolókat $(\mathrm{N}=129)$ és az egyéni sportolókat $(\mathrm{N}=49)$. Nem találtunk szignifikáns különbséget a két csoport mediánjai között ( $U=3014$; p=0,632), ami alátámasztja, hogy az áramlatélményre való fogékonyságot nem befolyásolja a sportág típusa, pontosabban fogalmazva az, hogy az adott sporttevékenységet egyénileg vagy csapatban űzik. Ugyancsak nem találtunk szignifikáns különbséget a férfi $(\mathrm{N}=80)$ és a női $(\mathrm{N}=98)$ sportolók között sem $(U=3715 ; p=0,548)$, tehát a válaszok alapján a sportoló neme sem befolyásolja a flow-élmények valószínűségét. Összehasonlítottuk a megyei $(\mathrm{N}=37)$, a harmad- $(\mathrm{N}=18)$, a másod- $(\mathrm{N}=39)$ és az első osztályú sportolókat $(\mathrm{N}=49)$, valamint a nemzeti válogatott kerettagokat $(\mathrm{N}=35)$ is, azonban a Krusal-Wallis próba eredménye alapján ebben az esetben sem találtunk szignifikáns különbséget a csoportok között $(\mathrm{p}=0,228)$.

\section{MEGBESZÉLÉS}

Kutatásunk során az áramlatélménnyel kapcsolatban több kérdésre kerestük a választ. Elsősorban a flow élmény és a teljesítménymotiváció, valamint az áramlatélmény és a kontrollhely kapcsolatát vizsgáltuk sportolók egy speciális rétegének körében. Emellett a flow univerzalitását is megvizsgáltuk a sport területére szűkítve. Legjobb tudomásunk szerint magyar sportolók esetében jelen vizsgálat volt az első, mely a teljesítménymotivációt és a kontrollhelyt az áramlatélményre való hajlamosság változójával összefüggésben vizsgálta, tehát a téma értelemszerűen kettős karrierű sportolók esetében is mindenképpen kiaknázatlan kutatási területnek minősül.

A statisztikai elemzést követően a vizsgálati eredményekre hivatkozva egyértelmű következtetéseket lehet levonni. A vizsgált sportolók válaszaira alapozva a teljesítménymotiváció mindkét alskálája, tehát a sikerorientáció és a kudarckerülés is 
összefügg az áramlatélményre való hajlamossággal. Előzetes elvárásaink helyesnek bizonyultak, miszerint a fundamentális áramlatkomponensekből kiindulva a sikerorientált személyek feladatválasztási preferenciái elősegíthetik, míg a kudarckerülőkéi akadályozhatják a flow-élmények megtapasztalását.

A belső kontrollos beállítódás ugyancsak mérhető, bár gyengének minősülő szinten korrelál a flow élményre való fogékonysággal, amire a külső kontroll mértékét jelző pontszámok és a flow pontszámok közötti negatív kapcsolat alapján következtethettünk. A belső kontrollos személyek úgy érzik, sorsuk a saját kezükben van, és ők irányítják az őket érintő eseményeket. Ugyanez igaz az áramlatélményre hajlamosabb sportolókra is, e párhuzamot sikerült empirikus adatokkal alátámasztanunk.

Ami az áramlatélmény univerzalitását illeti, a vizsgálati mintába tartozó sportolók között nincs szignifikáns különbség a vizsgált személyek neme alapján. Ugyanez igaz az egyéni és a csapatsportolók közötti különbségekre és a versenyzési szintre is, tehát az áramlatélményre való hajlamosságot e változók nem befolyásolják szignifikáns mértékben. A kapott eredmények egybevágnak Csíkszentmihályi koncepciójával, mely szerint a flow bárki számára megtapasztalható demográfiai jellemzőktől vagy tevékenységtől függetlenül (CSÍKSZENTMIHÁLYI, 2010). Ugyanerre a következtetésre jutott a releváns témában kutató Russel (2001), és egy 2008-as spanyol vizsgálat is alátámasztotta az áramlatélmény univerzalitását sportolók körében (MURCIA et al., 2008).

A kutatás célja a kettős karrierű sportolók vizsgálata volt, mely speciális rétegnek tekinthető a profi sport világában és csupán egy vékony rétegét képezik a sportolói társadalomnak. Emellett a vizsgált személyek mindannyian magyar nemzetiségúek, és egyaránt magyar egyetemek hallgatói, tehát a vizsgálati eredmények nem általánosíthatók sem a teljes sportolói társadalom szintjén, sem interkulturális szinten. Érdekes eredményeket hozhatna a kutatás kiterjesztése más nemzetiségü, akár teljesen más kultúrában szocializálódott sportolók vizsgálatára, mivel egy 1982-es metaanalízis eredményire hivatkozva a kontrollhely a kultúra függvényében változik (HUI, 1982). Ezen gondolatmenet alapján egy nagyobb kulturális diverzitással jellemezhető mintát vizsgálva feltételezhető, hogy az eredmények is módosulnának.

Mindazonáltal a fentiektől függetlenül a minta magyar viszonylatban reprezentatívnak tekinthető, tehát lokális szinten és a kettős karrierű sportolók körében megbízható következtetésekről beszélhetünk.

Végezetül érdemes kiemelni, hogy a sportflow további háttértényezőinek vizsgálata kulcsfontosságú, hiszen a flow és a csúcsteljesítmény kapcsolatából kiindulva az áramlat minél pontosabb megismerése sportpszichológiai és élsportolói szempontból is értékes gyakorlati haszonnal járó tudásra tehetünk szert.

A publikáció elkészítését a 2014-2020 - GINOP 2.3.2.-15-2016-00062 projekt támogatta. A projekt az Európai Unió támogatásával, az Európai Szociális Alap társfinanszírozásával valósult meg. 
Vol 3, No 2 (2020): Stadium-Hungarian Journal of Sport Sciences

\section{IRODALOMJEGYZÉK}

Carver C. S., Scheier, M. F. (2006). Személyiségpszichológia. Budapest: Osiris Kiadó.

Csíkszentmihályi M., Jackson, S. A. (2001). Sport és flow. Budapest: Vince Kiadó.

Csíkszentmihályi M. (2010). Flow. Budapest: Akadémiai Kiadó.

Fodor L. (2007). Fejezetek a motivációkutatásból. Budapest: Gondolat Kiadó.

Fodor B., Mihalik Á. (2017). A sikerkeresés és kudarckerülés motívumai, viselkedéses megjelenésük és összefüggéseik. Impulzus, 4, (1).

Fries S., Lang J. W. B. (2006). A revised 10-item version of the Achievement Motives Scale: Psychometric properties in German-speaking samples. European Journal of Psychological Assessment, 22, 216-224. DOI: https://doi.org/10.1027/10155759.22.3.216

Gimeno E., C., González-Cutre Coll, D., \& Murcia, J., A., M. (2008). Relationships among Goal Orientations, Motivational Climate and Flow in Adolescent Athletes: Differences by Gender. The Spanish Journal of Psychology, 11, (1), 181-191.

Hui C. C. H. (1982). Locus of control. A review of cross-cultural research. International Journal of Intercultural Realtions Relations, 6, (3), 301-323. DOI: https://doi.org/10.1016/0147-1767(82)90036-0

Jackson S. A., Marsh H. W., Smethurst C. J., \& Thomas P. R. (2001). Relationships between Flow, Self-Concept, Psychological Skills, and Performance. Journal of Applied Sport Psychology, 13, (2), 129-153. DOI: https://doi.org/10.1080/104132001753149865

Karteroliotis K., Stavrou,N. A., \& Zervas,Y. (2007). Flow Experience and Athletes' Performance With Reference to the Orthogonal Model of Flow. The Sport Psychologist, 21, 438-457. DOI: https://doi.org/10.1123/tsp.21.4.438

Oláh A. (1999). A tökéletes élmény megteremtését serkentő személyiségtényezők serdülőkorban. Iskolakultúra, 9, (6-7), 15-27.

Oláh A. (2005). Az optimális élmény mérésének lehetőségei: Egy új szituáció-specifikus Flow Kérdõív tesztkönyve. Budapest: HI PRESS.

Ravizza K. (1977). Peak experiences in sport. Journal of Humanistic Psychology, 17, (4), 35-40. DOI: https://doi.org/10.1177/002216787701700404 
Vol 3, No 2 (2020): Stadium-Hungarian Journal of Sport Sciences

https://doi.org/10.36439/SHJS/2020/2/8600

Rotter J. B. (1966). Generalized expectancies for the internal versus external locus of control of reinforcement. Psychological Monographs, 80, (1). DOI:

https://doi.org/10.1037/h0092976 